\title{
State Independent Electoral Commissions and local government elections in Nigeria
}

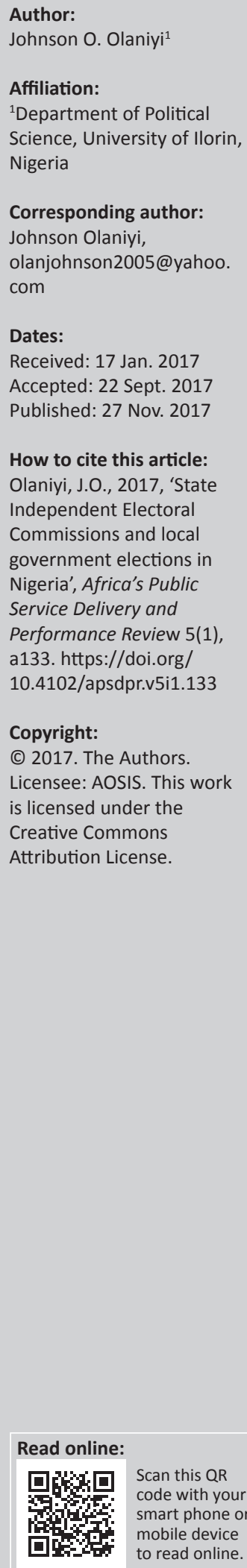

\begin{abstract}
Many state governments have not been allowing their State Independent Electoral Commissions (SIECs) to conduct elections as at when due but rather settle for 'caretaker committees'. Where elections have been conducted, the party in control of a state apparatus has been known to have cleared the polls. The general objective of this study is to assess the impact of electoral contest at the local government level on the political development of Nigeria. Specific objectives include (1) assessing the role of the political executives of a state in the determination of representation at the local government level in Nigeria; and (2) assessing the activities of SIECs in the management of local government polls. This study adopts comparative cum case study approach to analysing local government polls in Nigeria. This is discussed on a geopolitical basis. Some of the findings of the study include: (1) local government election in Nigeria is not given premium position by many state governments in the political landscape of their state because of the fear of playing into the hands of their political rivals; and (2) SIECs are only independent in name and not in practice. The study recommends, among others, that (1) the country should adopt the arrangement in the aborted Third Republic where the country's EMB was empowered to conduct all elections at all levels of government and (2) local government elections in Nigeria should key into the electoral process of the country in all ramifications.
\end{abstract}

\section{Introduction}

Nigeria used to be a unitary state. This was from January 1900 to 1954 when the country was officially colonised and the time it changed to federal system of government, respectively. Nigeria first experienced a decentralised form of administration in 1939 during the administration of Sir Bernard Bourdillon who was then the Colonial Governor-General of the country although there had been native councils and native courts in the northern part of the country before that time. This was done to oversee the administration of 'indirect rule system' (a system of rule that made use of traditional rulers who served as the intermediaries between their people and the colonial government) in that part of the country. His administration then divided the country into three administrative units namely: North, East and West. According to Nicolson (1979), this:

Step had the advantage of administrative convenience, as well as being a recognition of the social differences between the peoples who formed the majority in the West, the Yoruba, and those who formed the majority in the East, the Ibo. (p. 246)

The administrative units created by the administration of Sir Bernard Bourdillon later found expression into the 'Richard Constitution of 1946' named after the then Governor-General of the country, Sir Arthur Richard.

The Richard Constitution of 1946 converted the three administrative units created by the administration of Sir Bernard Bourdillon to political units. It did this by creating three Regional Assemblies. This was the most significant innovation of the Constitution. With the division of the country into three political units (regions), Sir Arthur Richard introduced the idea of federalism into the country's constitutional history.

The adoption of a federal system of government in Nigeria in 1954 made Native Authorities recognised as a tier of government in the country. However, they were under the control of each regional government and each regional assembly. In fact, they were not assigned specific (official) responsibilities by the various constitutions Nigeria had during the colonial period. This trend continued until the military regime of General Olusegun Obasanjo embarked on 'Local Government Reform' in 1976. The reform revolutionised local government administration in the country and accorded it an official recognition as the third tier of government. The 
reform'sought to address the role, the content of the system of local government, which hitherto, merely served as an appendage and extension of the existing local government (Otoghagua 2009:114).

Some of the major features of the 1976 Local Reforms include the following:

1. Creation of more local government areas (LGAs) in Nigeria with a provision that any local government can create subordinate local councils that must derive their power, revenue and personnel from the parent local government.

2. Introduction of elective principle into local government administration in the country. This study considers this as the most remarkable reform.

3. Local governments were to be financed by both the federal and the local government councils.

4. Exclusion of traditional rulers in the administration of local government councils. They were to perform consultative and advisory roles in the new dispensation. The reform also made provision for the establishment of 'traditional councils' which were authorised to deal with all chieftaincy traditional and cultural matters within an LGA (Otoghagua 2009:114).

The current local government system is predicated on the 1976 reform although the 1979 and 1999 constitutions have given official recognition to local government administration in the country. They have also defined in clear terms the structure and functions of local government councils. But of interest to this study is the aspect relating to local government polls (a system of elections) in the country.

\section{Conceptual clarifications}

A number of concepts that are considered germane to this study are to be examined in this section. They include the following:

1. Election.

2. Electoral Commission or State Independent Electoral Commission (SIEC).

3. Local government.

\section{Election}

Election and poll connote the same meaning. This explains why they are usually used interchangeably in political discourse. Election is the process of electing public functionaries into the different strata of the decision-making process. It is the most crucial stage of the 'electoral processes' because any mistake on the part of any of the electoral stakeholders can mar all other efforts.

Election as a concept has attracted a plethora of explanations from scholars of different climes and of different ages. Justice cannot be done to all of them in this work; rather the concept shall be explained in reference to few such positions.
Yakub (2010:33) explains elections as 'the processes through which leaders are appointed to and/or selected for an office'. He cautions that using the words 'appointed' and 'selected' should not connote that the free expression of the will of the people is compromised by the original and literal meanings of the words. What is more important is the process that produces public office holders. On this, he considers the existence of an independent election management body $(\mathrm{EMB})$ as the most essential ingredient to credible polls. However, it must be noted that Yaqub's definition of election is not pinned down to party politics which is the only platform through which candidates could be fielded for elections into public offices in a liberal democracy. Instead, it defines the concept in general term, that is, whenever the leadership of an organisation or establishment is determined via casting the votes or show of hands, election has taken place.

Dumoye (2010:1) explains election as 'the process of selecting one person or more for an office, public or private from a wider field of candidates'. Again, the lacuna of the definition of election proffered by Dunmoye is that it fails to associate election with party politics. Furthermore, the definition presents election as a routine that can be undertaken by all and sundry in a society, whereas the task of voting is not the prerogative of all and sundry in a society. Rather, before an individual can be allowed to participate in an electoral process, he or she must meet certain requirements.

This study is of the view that any definition of election in a political discourse must link election to party politics. This is found in the definition offered by Harris (1979). He defines election as 'an event which permits political parties to offer their programmes and candidates to those voters qualified to participate in election' (1979:327). This definition apart from linking election to party politics equally states that for anyone to be a participant in the electoral process, in this case, voter, he or she must possess certain qualifications. The question that is raised, however, is what happens in a situation in which a country practises 'zero party system' (a situation in which political parties are not in existence in a political system) and makes candidates contest elections on individual merit? Or what happens in a situation in which the constitution of a country allows the participation of 'independent candidates' in its electoral process as witnessed in Nigeria in the First Republic? Can election be said to have taken place? The position of this study to these issues is that once the electoral law or the constitution of a state has defined the nature of its electoral process, it does not run foul of the argument that any definition of election must have nexus with party politics. But more importantly, election has no substitute to produce the membership of a new set of ruling elites in any society. This position is in tandem with the view of Boynton (2001) who while stressing the importance of election in any democracy posits that:

Some are born to office, some rise through military or civilian bureaucracies, and some are elected to office. Election is a distinctive route into the political elite; it is an avenue that distinguishes legislators from most other members of a 
nation's political elite because their members are selected by election. (p. 280)

The above position is not, however, true of only the legislature in a liberal democracy. It includes other institutions. It also includes the executive arm at all levels of government (local government council inclusive). The importance of election is further seen in the fact that all things being equal, it produces 'responsive and responsible government'. It also performs the task of upward communication of people's wishes to a government. For instance, the electorate may vote against a sitting government because of some of its unpopular policies.

\section{Research questions, methodology and theoretical framework}

The study is guided by the following research questions: (1) What is the role of political executives of a state in the determination of representation at the local government level in Nigeria? (2) What are the activities of SIECs in the management of local government polls in Nigeria? (3) What are the imperatives of local government elections on the political well-being of Nigeria?

The methodology adopted for the study is the comparative cum case study method of analysing local government polls in Nigeria whereby a review of local government elections in Nigeria was made before narrowing it down to specificities.

The theoretical framework adopted for the study is the 'Independent Model EMB' espoused by Lopez-Pintor (2002 cited in Dennis 2010), which states that EMB as an institution of government must operate independent of interference from any organ of government or any of the stakeholders in the electoral process in the course of discharging its responsibilities as a subsystem in a polity.

\section{Electoral Commission or State Independent Electoral Commission}

Electoral Commission is the body saddled with the responsibility of organising and conducting election in a state. In most countries, they are usually constituted by the executive head of the country.

Mclean andMcMillan (2009) explain an electoral commission as:

A non-partisan body which determines election procedures and district boundaries and oversees the conduct of elections. (p. 165)

The above definition explains an Electoral Commission from the perspective of its major functions in any clime. But more importantly, it explains it as an apolitical institution. Its neutrality must not be faulted on any ground by the major electoral stakeholders. Any time the opposite is the case, the election it conducts will lose credibility.

Electoral Commission is usually branded differently from one political system to another. For instance, in Nigeria, at the federal level, it is currently known as the 'Independent
National Electoral Commission' (INEC), whereas it is known as the 'State Independent Electoral Commission' at the state level. This shows that Nigeria operates a bi-electoral commission system. In Zimbabwe, the body that organises and conducts election is referred to as 'Zimbabwe Electoral Commission' (ZEC). Regardless of the name they are given, electoral commissions perform similar functions across political systems. However the magnitude of such functions may differ from one clime to the other. But essentially, their main duty remains that of organising and conducting elections. In the case of Nigeria, Section 15 of the Third Schedule of the 1999 Constitution of the Federal Republic of Nigeria stipulates the powers of INEC. Of interest to this study is Section 15(a) which provides that INEC shall have power to:

Organise, undertake and supervise all elections to the offices of the President and Vice-President, the Governor and Deputy Governor of a State, and to the membership of the Senate, the House of Representatives and House of Assembly of each State of the Federation.(Federal Republic of Nigeria 1999:143)

This power excludes organising elections into local government councils in the country. This power is separately granted to another EMB known as 'State Independent Electoral Commission' by the Constitution.

Section 3 Part II of the Third Schedule of the 1999 Constitution of the Federal Republic of Nigeria makes provision for the establishment of SIEC. Section 4 of the constitution defines the powers of the EMB as:

1. to organise, undertake and supervise all elections to local government councils within the state

2. to render such advice as it may consider necessary to the INEC on the compilation of and the register of voters in so far as that register is applicable to local government elections in the state (Federal Republic of Nigeria 1999:148).

The above provisions reveal that SIEC has a sole role of organising and conducting elections into local government councils. This is unlike INEC that has the responsibility to organise and conduct elections at both federal and state levels. However, INEC remains the superior EMB because SIEC still avails itself of the voter register prepared by it. But operation wise, it does not perform any regulatory functions over SIEC. What this portends is that each of them enjoys a high degree of independence. Furthermore, while the federal government has constitutional power to constitute the membership of INEC as contained in the Section 154 of the 1999 Constitution of the Federal Republic of Nigeria, the same power is bestowed on state governors for the composition of SIEC as contained in Section 3 of Part II of the same constitution. Unlike INEC that has an organisational structure mainly composed of Chairman and National Commissioners, SIEC is made up of 'a chairman; and not less than five but not more than seven other persons' (Section 3, Part II of the 1999 Constitution of the Federal Republic of Nigeria:148). 


\section{Local government}

Local government is regarded as a tier of government in Nigeria. Nigeria operates three tiers of government, namely, federal, state and local. Section 7 of the 1999 Constitution of the Federal Republic of Nigeria gives local government system a legal impetus. The Section provides that:

The system of local government by democratically elected local government councils is under this constitution guaranteed; and accordingly, the government of every state shall subject to section 8 of this Constitution, ensure their existence under a law which provides for the establishment, structure, composition, finance and functions of such councils. (Federal Republic of Nigeria 1999:5)

McLean and McMillan (2009:213) define local government as 'a governing institution which has authority over a subnational territorially defined area; in federal systems, a substate territorially defined area'.The authors added that local government authority springs from its elected basis. Appadorai (2004:7) explains local government as government by the popularly elected bodies charged with administrative and executive duties in matters concerning the inhabitants of a partial or district or place.

The International Union of Local Government Authorities (IULA) defines local government as:

That level of government with constitutionality defined rights and duties to regulate and manage public affairs which are constitutionally defined for the exclusive interest of the local population. These rights and duties shall be exercised by individuals that are freely elected or appointed with the full participation of the elected body. (cited in Bello-Imam \& Uga 2004:7)

What is common with all the definitions of local government mentioned above is that they all see the system of government as an elected institution. This therefore negates the current practice of caretaker system in Nigeria.

Egonmwan's (1990) main contribution to the discourse on the literature definition of local government is the imperativeness of the system of government in any clime. According to him, local government is important because of the following reasons:

1. There are many amenities and services that can be best provided on a local basis rather than on central basis especially where the needs of the people are many and the resources of the central government are insufficient to cover all the requirements demanded.

2. The Central Government in most cases is remote from the local community and cannot be expected to know the individual wishes of the many communities carrying on their lives all over the country. This problem according to Egonmwan is better resolved by having local government.

3. Different towns and different districts have different traditions and customs perhaps different languages. These traditions and customs are better preserved under local government.
4. Local government provides a healthy spirit of competition between units of population making them jealous of each other's standard and eager to develop their own standard of living.

5. Local government provides a secured and peaceful background in which the individual members of the society may pursue their prosperity and happiness.

6. Local government provides services which members of society want and are prepared to pay for but as individual citizens they could not buy or provide for themselves, for example, roads and water supply (Egonmwan 1990:41-42).

This study is of the view that the importance of local government can only be transformed to reality through the effective discharge of its statutory responsibilities. For instance, the Fourth Schedule of the 1999 Constitution of the Federal Republic of Nigeria defines the main functions of a local government council in Nigeria. It is, however, imperative to add that a local government council can only effectively perform its functions in a conducive atmosphere that can only be guaranteed through its independence.

\section{State Independent Electoral Commissions and the conduct of local government elections in Nigeria}

Elections into local government councils in Nigeria did not take a uniform pattern abinitio. Beginning from 1951 to 1966 when the First Republic collapsed, native authorities (as what is currently known as LGAs used to be referred to) did not take a uniform pattern. Each regional government used to determine its own pattern of local government administration. The Western Region was the first in 1950s to pass legislation aimed at converting the colonial system of native administration - administration by traditional rulers, chiefs and elders - into a modern form of grassroots selfgovernment through elected representatives. The Eastern Region followed suit. In the Northern Region, though attempt was made to introduce an elective principle into the native authority system in the non-Moslem areas of the 'Middle Belt', Dudley (1982) reports that:

For much of the region, the colonial framework was retained with barely any change, what changed there was being simply the conversion of what used to be known as 'sole native authorities'- the Emir acting as sole administrator- into what was termed 'Emir-in-Council' that is a system in which the Emir was to be advised by his 'council' though he was under no obligation to accept what advice was proffered. (p. 110)

He however, notes that even in both western and eastern regions where there was holistic adoption of representative local government administration, local authorities became 'voting machines' for the ruling parties (Dudley 1982:110). This experience led to the suspension of most elected councils and in their place 'caretaker committee' composed of government nominees substituted. As will be revealed later 
in this work, this formed the basis of the current experience in Nigeria where most state governments prefer caretaker committees to elected councils in local government administration. During military administration, native authorities were run as a unified entity alongside with other levels of government. This continued till 1976 when the military administration of General Olusegun Obasanjo (retd) embarked on a comprehensive Local Government Reform in the country. As stated earlier in this work, it was the reform that gave a legal impetus to LGA as the third tier of government in Nigeria. But more importantly, the reform provides a uniform elective local government council. In line with this development, council polls were held across the country in December 1976. This was the first time a uniform council poll was held in Nigeria.

The 1976 council polls were contested on a non-party basis because Nigeria was then under a military rule. The 1979 Constitution of the Federal Republic of Nigeria bestowed the responsibility of conducting elections into the Federal and State elective positions on the Federal Electoral Commission (FEDECO) that was then the EMB of the country. Section 5 part $\mathrm{C}$ of the Constitution lists FEDECO as one of the Federal Executive Bodies. But for the first time in the electoral history of the country, the Constitution ceded the responsibility of conducting local government council elections to a separate EMB. This was 'State Electoral Commission' (SEC). Section 6 Part II (C) of the Constitution provides for the establishment of SEC. Section 7 Part II (C) of the Constitution defines the powers of the Commission as:

1. to organise, undertake and supervise all elections to local government councils within the state

2. to tender such advice as it may consider necessary to the FEDECO on the compilation of the register of voters in so far as that register is applicable to local government elections in the state (Federal Republic of Nigeria 1979:108).

Throughout the Second Republic, the above provision was not respected by local governments. Instead, they opted for caretaker committees. This was because it was the only platform by which they could ensure maximum control of local government councils because if elections were conducted, it was possible for opposition parties to control some of the councils.

The aborted Third Republic in Nigeria witnessed a drastic transformation of local government administration in the country. In fact, the tier of government witnessed stability occasioned by the provisions of the 1989 Constitution of the Federal Republic of Nigeria and promulgation of a number of decrees on local government administration.

Section 195 of the Constitution of the Federal Republic of Nigeria 1989 lists State Local Government Service Commission as one of the State Executive Bodies (Federal Republic of Nigeria 1989:75). Section 283 also provides that there will be a local government council for each LGA in the federation (Federal Republic of Nigeria 1989:102). In line with tenet of the Presidential System of government, the Constitution separated executive function from legislative duty. Sections 290 and 291 provide for the election of Chairman and Vice-Chairman of a council, respectively. Furthermore, Section 302 makes provision for the appointment of 'Supervisory Councillors'. Both represent the executive arm of the council. Section 298 of the Constitution also makes provision for the election of councillors which constitutes the legislative arm of a council (Federal Republic of Nigeria 1989:106).

It is imperative to note that the 1989 Constitution did not define in clear terms the powers of the then country's EMB, National Electoral Commission (NEC). Section 158 of the Constitution only provides that Federal Executive Bodies Created under Section 151 of the Constitution may with the approval of the President, by rules of otherwise regulate its own procedure or confer powers and impose duties on any officer or authority for the purpose of its functions (Federal Republic of Nigeria 1989:64).

Equally missing in the Constitution was 'State Electoral Commission', which was provided for under the 1979 Constitution of the Federal Republic of Nigeria. The implication of this was that NEC had the responsibility to conduct elections into local government councils in the country as well. Towards this end, NEC conducted the first nation-wide local government election on party basis in December 1990. It should, however, be noted that it had earlier conducted a local government election in 1989 although on a non-party basis.

The NEC was commended by some analysts for the way the December 1990 council polls were conducted. For instance, Ibrahim (1993:58) commenting on the election posits that:

The conduct of the election was very peaceful and the incidence of rigging very minimal compared to the past. (p 58)

The above position confirms the fact that when a central EMB conducts a local government poll, its outcome will be more credible than a situation in which an SEC (which is under the control of a state apparatus) conducts same election. This advantage was, however, eroded by the provision of the 1999 Constitution of the Federal Republic of Nigeria which reverted the arrangement to the pre-1989 status.

As earlier stated in this work, the 1999 Constitution of the Federal Republic of Nigeria which is the enabling legal instrument of the Fourth Republic provides for decentralised form of EMB. While INEC, created by Section 153 of the Constitution, organises and conducts elections into federaland state elective positions, Section 3, part II of the Third Schedule of the Constitution, provides for the establishment of SIEC which has power to conduct local government polls. But while INEC is a 'Federal Executive Body', SIEC is a State Executive Body. The findings of this study have revealed that 
while INEC has been allowed to enjoy some degree of independence in the cause of performing its statutory responsibilities, SIECs have become a ready tool of perpetrating electoral frauds during local government elections.

This is made possible because the chairman and members of 'State Independent Electoral Commissions' are either cardcarrying members of the ruling political party in the state or associates of the governor. This explains why each time a new SIEC is constituted by any state government, opposition parties usually criticise the exercise. It further shows why members of the public and opposition parties in particular do not usually have respect for the outcomes of elections conducted by SIECs. What is responsible for all these is that the 1999 Constitution did not define in clear terms the independence of SIEC.

Again, unlike the 1989 Constitution that states that local government elections be held every three years, the 1999 Constitution is silent over this. Therefore, local government councils exist at the whims and caprices of state governors. Consequently, when a political party is defeated during a governorship election, one of the primary tasks of the new regime is to dissolve the inherited councils. One of the reasons usually advanced to justify this action is that some state governors always give the go-ahead order to their SIECs to conduct local government polls at the verge of their exit. A case in point was the experience of local government councils in Rivers State in 2015. The immediate past governor of the state, Rotimi Amaechi, directed Rivers State Independent Electoral Commission (RSIEC) to conduct a local government election poll on 23 May 2015, just six days before its exit from office. This was after the candidate of the then ruling party in the state, All Progressives Congress (APC), Mr Peterside had been defeated in the March 2015 gubernatorial election by the candidate of an opposition party, Peoples Democratic Party (PDP), in the state, Mr Nyesom Wike. The election was boycotted by the members of PDP. The party that had earlier filed a court action against the decision of the administration of Governor Rotimi Amaechi got justice on 09 July 2015 when a Port-Harcourt High Court dissolved the councils that were all won by the candidates of APC, on the ground that the election was held in violation of court order (Nigerian Tribune, 10 July 2015:4). The question that arises from the scenario is what could have prompted the action of Amechi's administration to conduct a local government poll after its political party (APC) had been defeated in the governorship election knowing full well that the incoming administration of another party (PDP) has constitutional right to constitute SIEC? The answers to this question are twofold. One, the then outgoing administration of Rotimi Amaechi wanted to plant its surrogates in power so that while PDP is controlling the state affairs, APC will be at the helm of affairs at the local government level. Two, although the lifespan of a local government council in Rivers State is three years, the new government could hide under the canopy of the court judgement of 09 July 2015, which ruled that the 23 May 2015 local government election in Rivers State was conducted in violation of court order.

Many state governments are guilty of the same offence the then Rotimi Amaechi's administration was guilty of but like what happened in Rivers State, whenever there is a change of government, their antic cannot be sustained. For instance, local government election was held in Ondo State on 23 April 2016, nine months before the expiration of the second term of the administration of the governor of the state, Dr Olusegun Mimiko. The election was the first in the last seven years. What this suggested was that a local government poll had not been held in Ondo State since the year 2008 when the administration of Governor Olusegun Mimiko came on board. Instead of having elected councils, the governor resorted to caretaker committees who were members of his party or associates. With this strategy, his (governor's) party (formerly Labour Party-LP and later PDP which he defected to in 2014) had a good grasp of the state. The election was boycotted by the major opposition party in the state (APC) but contested by 14 other opposition parties. 'Expectedly', all the chairmanship and councillorship positions were won by the PDP, the ruling party in the state. The outcome of the governorship election that was later held in the year in Ondo State on 26 November 2016 runs contrary to the results of the local government poll conducted in April 2016. PDP which is the ruling party in the state and which won all the 18 local government chairmanship seats was defeated by the opposition party, APC. The candidate of the opposition party in the state, Mr Rotimi Akeredolu, polled a total of 244842 votes to defeat Mr EyitayoJegede who garnered 150380 votes (The Punch, 28 November 2016:1). The issue arises is if PDP was as that popular in the state as the result of April 2016 poll reflected, it should have won the gubernatorial election of November 2016 as well.

Kwara State and Ogun State are one of the few states in the federation that have been holding local government polls regularly although the outcomes of such elections usually tilt towards the interest of both state governments. The last time Kwara State government held a local government election was October 2013. The tenure of the councils expired in October 2016 and the state government constituted caretaker committees in November 2016. The outcome of the election of 2010 revealed that the ruling party won the chairmanship positions in the 16 LGAs of the state. It also won all the councillorship positions in the 193 wards of the state. The outcome of the election by our own understanding was a mere political game which did not portray electoral contest in its true spirit. In fact, in the local government held in the year 2010, Offa Local Government which is one of the LGAs in the state, was won by an opposition party, Action Congress of Nigeria $(\mathrm{ACN})$, but the ruling party in the state at that time, PDP, 'manipulated' judicial process to reclaim the area. In the recent local government, election held in Ogun State in October 2016, APC, which is the ruling party in the state, won all the 20 chairmanship seats into the 20 local government councils in the state. It also captured 228 of the 234 
councillorship seats in the state living opposition parties with 5 . In fact, according to the result released by the Ogun State Independent Electoral Commission (OSIEC), the main opposition party in the state, PDP, only garnered two councillorship seats, while the less popular party in the state, Peoples Party of Nigeria (PPN), won three seats.

The foregoing makes any observer believe that the outcomes of local government polls in Nigeria have not been a true reflection of the wishes of the electorate. What usually takes place is mere allocation of scores to candidates. This justifies why members of opposition parties at the state level always see local government elections as a mere political game, an electoral routine and an exercise they should not waste their resources on.

As at the time of this research, about $75 \%$ of states in Nigeria do not have elected councils. More worrisome were cases of some states that have not conducted local government elections in the last 7-8 years. Instead, they have resorted to caretaker committees, undemocratic bodies, to actualise their political cum economic ambitions at the grassroots level. A case in point is Oyo State Government that has not conducted local government polls in the last nine years. The strategy it has been adopting is to write the State's House of Assembly (the legislative arm of state) for the renewal of the tenure of caretaker committees at the expiration of one. It was only in November 2016 that the governor of the state, Mr Isiaka Ajimobi, made a policy statement that local government election will be held in the state in February 2017. People are not so enthusiastic about this promise because similar statements had been made by him in the past without being redeemed. An example of such sceptics is Comrade Jaiye Gbobagoke, a social critic and a trade union leader in Oyo State, who posited that:

No one should be carried away by the Governor's (Ajimobi's) promise. He has made similar promises in the past unredeemed, moreso, his predecessor in office, Chief AlaoAkala, was guilty of the same offence. (The Courier, 25 November 2016:4)

Another good example of a state that did not hold local government elections in Nigeria for some time is Anambra State. The immediate past administration of Governor Peter Obi was guilty of the allegation. Governor Willie Obiano came to power through the platform of the then ruling party in Anambra State. This was 'All Progressive Grand Alliance' (APGA). However, the then governor of the state, Mr Peter Obi who came to power as the governor of the state in 2003 through the platform of APGA shortly fell out with the leadership of the party. The founding father of APGA was Chief Odumegwu Ojukwu the former warlord leader of the botched Biafran Republic and the undisputed Igbo (ethnic group) leader of his time. Consequently, the then Governor Obi who fell out with some Igbo leaders must have considered it a political suicide conducting a local government election in a state where he could not out match the popularity of Chief Odumegwu Ojukwu. However, riding on the popularity of APGA in the state, the administration of Governor Willie Obiano has since conducted local government elections.

In Imo State, the failure of the administration of Governor Rochas Okorocha to hold local government elections since 2011 when he came to power borders on political reason. Governor Okorocha came to power in 2011 under the platform of APGA by defeating the candidate of the PDP in the election. However, in 2013, Governor Okorocha defected to APC by leading a faction of the APGA to its formation. This scenario shows that there are currently three 'popular' parties on ground in Imo State - PDP, APGA and APC. Consequently, any arrangement leading to the conduct of local government election may turn out to be political suicide for the administration of Governor Rochas Okorocha. Therefore, the popularity of PDP and APGA in Imo State can be seen as what APC cannot dismiss with a whisker at least going by the outcome of the 2015 general elections. Although APC won the gubernatorial election perhaps because of the popularity of Governor Rochas Okorocha, the outcome of the elections conducted to the National Assembly (Nigeria's central legislature) revealed otherwise. For instance, the PDP won all the three senatorial seats in the state during the election. This showed that PDP remains a strong political party in the state. Be that as it may, all things being equal, whenever a local government election is conducted in the state, PDP will control some local government councils. This will definitely precipitate political bickering between the local government councils concerned and the state government.

The failure of state governments (Borno, Yobe, Bauchi Gombe, Yola, Adamawa and Taraba) in the north-east geopolitical zone of the country borders on the issue of security. Since 2002, when Boko Haram group (an avowed Islamic sect) was founded by Muhammad Yusuf, north-east geopolitical zone had not known peace. Respite was just gradually coming their way when President Muhammad came to power. With the death of the founder of the group, Muhammad Yusuf, in a police cell in 2009, 'the group turned insurgents'. In fact, between 2012 and 2015, it controlled about 14 of the 23 LGAs in Borno State which was the operational base of Boko Haram. Yobe and Adamawa states did not fare better neither. There were constant attacks from Boko Haram insurgents and more often than not their targets used to be Local Government Secretariats and public institutions especially primary schools. The other three states in the geopolitical zone of the country - Taraba, Bauchi and Gombe - equally recorded a good number of insurgency attacks. The foregoing gives justification for the failure of state governors to organise local government polls in the north-east geopolitical zone of the country since 2009 .

Furthermore, economic reason can be advanced for the failure of some state governments to hold local government elections in Nigeria. This has two sides. One of the sides is the group that fails to conduct local government election because of their poor state of finance. The second is the group of state governments that technically refuses to conduct local 
government elections simply because they will continue to feed on the appropriation for local government councils coming from the Federation account.

On the first group which hinges their failure to conduct local government polls because of their poor financial status, the argument that arises is about what financial commitment such states have towards the exercise; after all, appropriations of local government councils usually come from the federal government. Because LGAs are technically attached to state governments at least going by Section 3, Part II of the Third Schedule of the 1999 Constitution that empowers a State Government to constitute SIEC, it can be argued that LGAs are not independent of the State Governments. This explains why the governor of Osun State (one of the 36 states in Nigeria) Mr Rauf Aregbesola recently posited that there are two levels of government in Nigeria - federal and state. He made this statement in response to the allegation levelled against state governors by the Speaker of House of Representatives, Honourable Yakub Dogara, that they were mishandling the allocations of local governments from the Federation account. This according to him is an impeachable offence. Mr Rauf Aregbesola, the governor of Osun State, was quoted to have said that:

Local Government Councils are absolutely under the control of the States, and that the only organ of the state empowered by the Constitution to make laws for them is the state parliament. (Alao 2016b:6)

Governor Rauf Aregbesola described the view that local government councils should be independent as totally strange and anti-federalism and that there are two tiers of government in a federal system.

In the group of state governments that technically refuses to conduct local government elections because of the financial benefits they are deriving from local government councils, the majority of state governments are guilty of this allegation. The strategy they usually adopt is that as soon as local government appropriation gets to them from Federal account all in the name of 'Joint Account', they withhold a large percentage of it and release 'peanuts' to the councils. However, as caretaker committee members are governor's appointees, the latter will still decide for them on the capital projects to embark on in their areas. Where contracts are to be awarded, it is state governments that do the biddings. The foregoing explains why the Speaker of House of Representatives (Nigeria's Lower Legislative Chamber) hinges the problem of local government councils on lack of independence. He considers this as the bane of local government in Nigeria (Alao 2016a). On the problem of financial autonomy confronting local government councils in Nigeria, Honorable Dogara posited that:

There is lack of independence because they (Local Government Councils) are subsumed in the control of the State executive that things appear not to be flowing. As a matter of fact, joint account is one of the biggest evils because it gives the authority to local government ministries in the state. In most states, especially in the North where we don't have oil and so on, the ministry of local government in the state is regarded as the ministry of petroleum resources. So we all know when funds are allocated to the councils, they are hijacked at that level and appropriated according to the whims of the powers that be. (Alao 2016a:24)

The above position of the Speaker of the House of Representatives in Nigeria who is the fourth citizen of the country speaks volumes on the current travails of local government councils in Nigeria. In fact, currently, some local government councils owe their workers salary arrears. A case in point is Kwara State where workers (pensioners inclusive) who receive their salaries through local government councils are owed about 5-6 months salaries depending on their grade levels. More worrisome is the discrimination of Kwara State Government against local government workers. State workers receive their salaries when due but the state government always claims that local government workers are not its (Kwara State Government) employees. But as posited earlier, the state government cannot be insulated from the failure of local government councils to pay the salaries of their workers:

The foregoing explains why about $75 \%$ of states or Federal Capital Territory (FCT) have unelected local government councils. They have found respite in the unconstitutional caretaker committees that cannot challenge any of the draconian actions of state governments against them. Consequently, unless an urgent action is taken by the powers that be to amend the constitution, Nigeria will one day get to the stage of not having a single elected local government council.

\section{Findings, policy and recommendations}

From the study, a number of observations can be made. They include the following:

1. Local government councils in Nigeria are not independent of state governments because, for instance, their appropriations from the Federation account get to them through the state government. This gives the former the undue advantage to hijack them all in the name of Joint Account.

2. Political reason can be advanced for why many state governments have resorted to the use of caretaker committees as opposed to elected councils. Because of the fact that most states are composed of political parties having more or less equal electoral strengths, conducing local government polls will amount to ceding some councils to opposition parties.

3. Economic reason also explains why some state governments seldom conduct local government elections. Because of how practically all state governments feed fat on the local government councils with regard to their federal allocations, conducting local government elections will reduce such benefit. Furthermore, the poor financial status of some state governments accounts for why they cannot conduct local governments elections. 
4. Security challenges in some parts of the country, especially north-east, have prevented state governments to order their SIECs to conduct local government polls.

5. Caretaker committee syndrome is unconstitutional because it has no basis in the 1999 Constitution of the Federal Republic of Nigeria. Also unconstitutional is the action of some state governments in dissolving elected local government councils and constituting caretaker committees. In fact, in cases where such actions have been challenged by the members of the dissolved councils in courts (until the December 2016 judgement of the Supreme Court of Nigeria), they have not gotten 'justice' as either some courts upheld the actions of such governors or, where counts have ordered that they should be reinstated, such rulings have always been rebuffed by state governments. A case in point was the experience of the members of the dissolved councils in Rivers State in 2015 earlier cited in this study.

6. Most state governors are intolerant to opposition thus explaining why they will not want any local government council in their states to be under the control of an opposition party. The case of Offa Local Government Area, Kwara State, in 2010 earlier cited in this study readily comes in here. Until their dissolution in October 2016, all the local government chairmanship seats and councillorship positions in Kwara State were controlled by APC which is the party at the helms of affairs in the state. This study views this as antithetical to democratic norm in any liberal democracy.

Based on the above findings, the study hereby makes the under-listed policy recommendations to enable SIECs to perform their statutory responsibilities and free them from the bondage of state governments as long as Nigeria runs three tiers of government. This is necessary to put a stop to local government councils serving as 'voting machines' for the ruling political parties at the state level.

1. Local government councils should be made independent. Section 7 (1) of the 1999 Constitution that gives legal impetus to local government system as a tier of government in Nigeria places local government councils under the control of state government. It provides that state governments should ensure their existence under a law that provides for the establishment, structure and composition, finance and functions of such councils. This study considers this as the bane of local government administration in Nigeria: local government councils should be treated as an independent entity like states, unattached to either state or federal government. Just as powers are shared between state governments and federal government, the same should apply to local government councils. In the current dispensation, local government councils are not independent in Nigeria. This was what captured the mind of Honorable Yakubu Dogara, Speaker of the House of Representatives, when he made a case for the independence of local government councils in Nigeria. He gave insights into the paraphernalia of the independence of local government councils in any political system when he stated that:
Now, when we talk about independence of local government councils in Nigeria, I don't know whether it is achievable, whether we should talk about certain semi-autonomy or some kind of semi-independence. Because when you are talking about independence of local government councils they have a democratically elected council, a democratically elected council legislature. You have council police; you have councils that are directly in charge of recruiting their personnel and disciplining them. You have legislators. The chairmen operate as the executive and they can be impeached if they go against certain rules and so, they are completely independent and as such, they deliver on mandates that are given to them (Alao 2016a:24).

2. Closely related to the above recommendation is that SIECs should be abrogated and the central EMB of the country (INEC) be made to be conduct local government elections. If adopted for action, this will give electoral stakeholders during local government polls confidence in the ability of INEC to organise and conduct credible elections. The current arrangement exposes SIECs to partisanship which runs foul of the international standard of conducting free and fair elections by any EMB. In essence, for any election to meet international standard, the EMB that conducts such election must be seen to be neutral, in any ramifications. INEC is the EMB that conducts local government councils polls in the country's FCT, Abuja. Since 1999, when INEC has held this responsibility, major challenges have not been recorded. In fact, in the last FCT Council poll it conducted in 2015, PDP which is currently the main opposition party in Nigeria won two of the three chairmanship positions in the FCT council.

3. The practice of dissolving duly elected local government councils by state governors and replacing them with the undemocratic caretaker committees should be constitutionally disallowed. Currently, the practice has no hiding place in the 1999 Constitution of the Federal Republic of Nigeria. What this portends is that the action of state governors who have sacked elected councils runs afoul of the constitution. Consequently, provision should be made in the future review exercise of the constitution stipulating punitive measures for erring state governors. The 9 December 2016 Supreme Court (the apex court of Nigeria) judgement on the sacked local government council's chairmen in Ekiti State (of Nigeria) has addressed the foregoing problem. The 16 local government chairmen were elected in 2008 but got sacked by the administration of former Governor Kayode Fayomi on 16 October 2016, two days after he was sworn in as the governor of the state. His action was challenged in court by the affected council chairman. In its judgement, the Supreme Court ordered the Ekiti State Government to pay all the 15 months entitlements, allowances and emoluments of the council officials illegally removed in 2010 (Nwaoko 2016:5). This decision that affirmed the January 2015 Court of Appeal decision on the matter confirms the earlier position of this study that dissolution of elected councils by state governments before the expiration of their tenure is illegal. However, this study is of the view that the judgement will bring sanity to local government administration in Nigeria. 
4. This study has revealed that the main reason why state governments prefer caretaker committees to elected councils borders on the misappropriation of the allocation of local government councils funds by state governments. To stop the trend, this study recommends the abolition of 'Joint Account' which state governments use to milk local government councils. Instead, allocations should be made directly to local government councils without the involvement of state governments.

This study is of the view that if the above-highlighted recommendations are adopted for adoption by powers that be in Nigeria, local government polls in the country will not be a mere political game but an electoral contest that can stand the test of time.

\section{Conclusion}

This study has examined the role of SIECs in the organisation and conduct of local government elections in Nigeria. It starts with introduction first and then conceptual clarifications. The study later progresses to the stage of discussing the main thrust of the work, that is, the examination of the role of SIEC in conducting local government elections in Nigeria. This aspect of the study begins with a historical analysis of local government administration in Nigeria before zeroing it down to the era of having a separate EMB to organise and conduct local government polls in Nigeria. Although this began with the 1979 Constitution of the Federal Republic of Nigeria, SIECs were not allowed to function effectively then because most state governments resorted to the use of caretaker committees. Also, the central EMB in the country then, FEDECO, conducted elections into the local government councils of the few states that opted for elected local government councils.

The military era of General I.B. Babangida (retd) witnessed a reversion to the old order in which the central EMB in the country had statutory responsibility to conduct local government polls. Consequently, NEC which was the country's EMB that conducted elections in the aborted Third Nigerian Republic had constitutional responsibility to conduct local government election. In the current Nigeria's Fourth Republic, the 1999 Constitution bestows the responsibility of conducting local government elections on the SIEC. But the bone of contention has always been the degree of freedom enjoyed by SIECs in the performance of their statutory responsibility.

\section{Acknowledgements}

The author would like to thank the State Independent Electoral Commissions in Nigeria for their support in the area of making available to him necessary documents on the elections they have conducted so far in the Fourth Republic.

\section{Competing interests}

The author declares that he has no financial or personal relationships which may have inappropriately influenced him in writing this article.

\section{References}

Alao, M., 2015 'Court dissolves rivers L.G. Councils', Nigerian Tribune, 10 July, p.4 Alao, M., 2016a, 'Governors can be impeached for what they do to local governments', Sunday Tribune, 04 December, p. 24

Alao, M., 2016b, 'Showdown: National assembly, governors to clash over loca governments', Sunday Tribune, 04 December, p. 6.

Alechenu, J., 2016, 'Results of Ondo guber poll', The Punch, 28 November 2016, pp. $1-3$.

Appadorai, A., 2004, The substance of politics, Oxford University Press, New Delhi.

Bello-Imam, I.B. \& Uga, E., 2004, 'Nigerian local government as a third-tier of government: Myth or reality?', in I.B. Bello-Imam \& M. Obadan (eds.), Democratic governance and development management in Nigeria Fourth Republic, 19992003, p. 7, JODAD Publishers, Ibadan.

Boynton, G.R., 2001, 'Legislatures', in M. Hawkesworth \& M. Kogan (eds.), Encyclopedia of government and politics, vol. 1, p. 280, Routledge, London.

Dennis, F., 2010, Election management, Bark \& Post Publishers, New Delhi.

Dudley, B., 1982, An introduction to Nigerian government and politics, MacMillan Press, London.

Dumoye, R.A., 2010, 'Nexus of democratic consolidation and development imperative in Africa', in K. Mato (ed.), The democracy question and election management in Africa, pp. 1-14, Daily Graphics Nigeria Ltd., Ibadan.

Egonmwan, J.A., 1990, Principles and practice of local government in Nigeria: An insight into the problems of public policy formulation and implementation, S.M.O. Aka \& Brothers Press, Benin City.

Federal Republic of Nigeria, 1979, The constitution of the Federal Republic of Nigeria, Department of Information Printing Division, Lagos.

Federal Republic of Nigeria, 1989, The constitution of the Federal Republic of Nigeria, NERDC Press, Lagos.

Federal Republic of Nigeria, 1999, Constitution of the Federal Republic of Nigeria 1999, Federal Government Press, Lagos.

Harris, P.B., 1979, Foundations of political science, Hutchinson \& Co. (publishers) Ltd, London.

Ibrahim, O.F., 1993, 'Elections in the transition', in T. Adeniran (ed.), Seven years of IBB volume 7: The transition, p. 58, The Daily Times of Nigeria Plc, Lagos.

McLean, I. \& McMillan, A., 2009, Oxford concise dictionary of politics, Oxford University Press, Oxford.

Nicolson, I.F., 1979, The administration of Nigeria 1900-1960: Men, methods and myths, Oxford University Press, Oxford.

Nwaoko, S., 2016, 'Sacked Ekiti L.G. Chairman get justice after 6 years', Saturday Tribune, 10 December, p. 5.

Otoghagua, E., 2009, Trends and contemporary issues on regimes of Nigerian Heads of State: Policies and politics, achievements and failures, Otoghagua Enterprises, Benin.

Oyetoyan, K. M., 2016 'Oyo state to hold L.G. polls in 2017', The Courier, 25 November, p. 4.

Yakub, N., 2010, 'Consolidating democracy in Nigeria: Emerging challenges from the 2007 general elections', in K. Mato (ed.), The democracy questions and election management in Africa, p. 33, Daily Graphics Nigeria Ltd, Ibadan. 